Sepětí mezi Vančurou a Mahenem se projevilo i v oblasti dedikací - Vančura připsal Markétu Lazarovou Mahenovi a Mahen mu věnoval Požár Tater. Jiřímu Poláčkovi budiž dodán alespoň tento neumělý rispet:

Fiři stojí za milírem, sleduje portréty a osudy, ovívá se modrým vějírem, prost jakékoliv ostudy.

Uběhl nový básnický rok, $v$ němž učiněn další krok $k$ tvorbě a recepci $v$ mahenovském kotci.

František Všetička

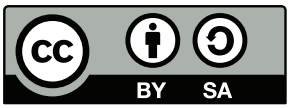

Toto dílo Ize užít v souladu s licenčními podmínkami Creative Commons BY-SA 4.0 International (<https:// creativecommons.org/licenses/by-sa/4.0/legalcode>). Uvedené se nevztahuje na díla či prvky (např. obrazovou či fotografickou dokumentaci), které jsou v díle užity na základě smluvní licence nebo výjimky či omezení př́slušných práv.

\title{
https://doi.org/10.5817/OS2021-1-10
}

\section{Odešel prof. PhDr. Miroslav Zahrádka, DrSc.}

25. května, kratičce po svých 90. narozeninách, ukončil své životní putování rusista, literární vědec, literární a divadelní kritik, publicista, překladatel a spisovatel prof. PhDr. Miroslav Zahrádka, DrSc., dlouholetý vedoucí rusistického a slavistického pracoviště na Filozofické fakultě Univerzity Palackého v Olomouci.

Profesor Zahrádka se narodil 14. května 1931 v Kralupech nad Vltavou. Tam absolvoval školní docházku včetně gymnaziální, po ní následovalo studium ruštiny a češtiny na Filozofické fakultě Univerzity Karlovy v Praze. Krátké působení na Vysoké škole ruského jazyka a literatury tamtéž bylo vystřídáno aspiranturou v Moskvě, která se stala dobou poznávání reálného stavu společnosti v Sovětském svazu a navazování prátelství s mnoha osobnostmi ruské literatury i literární vědy. Od roku 1960 pak bylo a je jméno Miroslava Zahrádky spjato s Olomoucí a olomouckou rusistikou, kterým zůstal věrný až do svého odchodu do důchodu, po němž podle toho, jak mu dovolovaly síly, pořád ještě pracoval. 
Svou nikoli nekomplikovanou životní pout naplňoval profesor Zahrádka všestrannými zájmy a neskutečně pilnou pracovní činností. Jeho odborné zájmy patřily nejen studiu ruské literatury, a to od klasické až po aktuální dění v posledních desetiletích 20. století, ale zajímal se i o historii recepce a překládání ruských autorů v českém prostředí (sám i překládal), sledoval vývoj česko-ruských literárních a kulturních vztahů, intenzivně se věnoval recenzní činnosti; živě se zajímal o kulturní dění kolem sebe a v tomto ohledu jej kromě ruské prózy přitahovalo divadlo.

Jeho celoživotním tématem se stalo zobrazení války v ruské literatuře, kterému se kromě rady statí věnoval zejména v publikacích $O$ vývoji ruské válečné prózy: téma žánr - styl (1812-1853) z roku 1969, Stalingradská bitva v literárním zobrazení: téma žánr - styl (1973), Michail Šolochov. Motivy - kompozice - styl (1975), Literatura a válka: etapy a tendence zobrazení Velké vlastenecké války v sovětské literatuře (1980) a posléze v monografii Lev Nikolajevič Tolstoj a ruská próza. Stránky z historie ruské válečné prózy 1812-1917 (1996). Př́kladné je v těchto pracích jeho lpění na sepětí analýz s texty literárních děl, tendence bránit se čemukoli zobecňujícímu, co by neměl dostatečně faktograficky či důkladnou analýzou primárních textů podloženo.

Česko-ruské vztahy a historie recepce a překladů ruských autorů u nás byly dalším polem jeho zájmu, jak o tom svědčí mimo jiné práce Alexandr Fadějev a Československo (1976, spoluautorem byl ústecký rusista a germanista Ctirad Kučera), Sovětská literatura a my (1981), Paralely a vztahy: Česká a sovětská poválečná próza (1986) či Maxim Gorkij v ohlasech české kritiky prélomu 19. a 20. století (2001). Profesor Zahrádka také vedl autorský kolektiv Malého slovníku rusko-českých literárních vztahů (osobnosti ruské literatury $v$ českém kontextu) (1986), který byl kolektivním dílem, ale nikdy by nebyl vznikl bez Zahrádkovy iniciativy a bez jeho vytrvalosti. Totéž platí i pro na něj navazující a výrazně rozšiř̌ný Slovník rusko-českých vztahư (2008). Do této „přihrádky“ určitě patří i Zahrádkovy osobní vzpomínky na některé osobnosti ruské literatury, které zahrnul do knihy Toulky s ruskými spisovateli (2007).

Stranou nelze ponechat Zahrádkovu snahu o tvorbu publikací určených sice primárně pro pedagogické účely, ale i v tom případě přsahujících úzce pojatou didaktickou roli. Do této rubriky Zahrádkovy přepestré publikační činnosti lze zařadit mimo jiné publikace Současná sovětská literatura: Próza, poezie, drama (1984, ve spoluautorství s Miroslavem Mikuláškem a Dušanem Žváčkem), Literaturnyje tečenija i ličnosti russkoj literatury XX veka I-II (2000-2001, spoluautorkou byla Jana Sováková), Ruská literatura XX. století: (literární proudy a osobnosti) (2003), př́padně Ruská literatura XIX. století v kontextu evropských literatur. Osobnosti a dialog literatur (2005).

Už jen suchý a neúplný, o to ale úctyhodnější výčet Zahrádkových prací prokazuje jeho pracovitost a všestrannost, jeho vytrvalost i snahu hledat spolupráci s ostatními tak vznikala jak jednotlivá spoluautorství, tak i prostor pro diskusi, které se profesor 
Zahrádka nebránil, ba naopak, vyhledával ji. Uvědomoval si dobově danou úzkost a ideologické zploštování ve společenském i literárním prostředí, vnímal jimi ovlivněné mezilidské vztahy a nebál se leccos zpětně ve svých vlastních názorech korigovat či naopak s jistou osobní notou a (sebe)kritičností komentovat, jak o tom svědčí nejen jeho Dogmata a živý literární proces (fak vznikala úzká norma socialistického realismu a jak s ní ruská literatura bojovala) (1992), ale i řada míst v jeho Okamžicích ze životního putování literárního vědce a prozaika (2011). Připočíst je $\mathrm{k}$ tomu všemu potřeba nesčetné články v odborném tisku doma i v zahraničí, vystoupení na mnoha konferencích, přednášky $\mathrm{v}$ různorodých institucích - jen tak lze získat představu o Zahrádkově pracovitosti a vytrvalosti, o jeho znalosti faktografie i schopnosti nadhledu. Více snad př́padnému zájemci nabídne Zahrádkova Bibliografie (2010).

Profesor Zahrádka je i svého druhu „otcem-zakladatelem“: stál u zrodu Olomouckých dnů rusistů, původně do jisté míry osvětového setkávání učitelů ruského jazyka a literatury, jež se nakonec staly významnými a vyhlášenými mezinárodními konferencemi. Jeho jméno je spojeno i s počátky původně ročenky katedry rusistiky FF UP, nyní odborného časopisu Rossica Olomucensia, s konferencemi pořádanými ve spolupráci s Mezinárodní asociací učitelů ruského jazyka a literatury (MAPRJAL) stejně jako se sborníky, jež z nich vznikly.

Tento spíše faktografický výčet není ani úplný a vůbec už ne vyčerpávající, pokud by bylo vůbec možné vše zmínit (stranou zůstává jeho překladatelská a spisovatelská práce), a proto si dovolím nevynechat ani zcela osobní vzpomínku na aspirantské semináře, které z iniciativy profesora Zahrádky v Olomouci probíhaly. K němu stejně jako k prof. Kostřicovi a docentu Žváčkovi jsme se pravidelně sjižděli jako mladí asistenti z Brna, Ostravy, Hradce Králové, Ústí nad Labem i Plzně a v prostorách olomoucké katedry četli své referáty, navzájem diskutovali (pokračovali jsme pak i za restauračním stolem) a poslouchali jejich komentáře $k$ našim vystoupením. Bylo to volné, svobodné, neautoritativní a nenásilné, rodily se tam nápady, ale dozvídali jsme se i to, co bychom ještě měli či mohli nastudovat. Vznikala tam prátelství, která přetrvávají dodnes. Bylo to - a dnes mi to chybí, takže za to o to víc děkuji - lidské, tolerantní i přátelské. Postupně se z úcty $\mathrm{k}$ autoritám stávalo partnerství a olomoucké pracoviště tak $\mathrm{v}$ té době bylo vlastně jakýmsi centrem výchovy nás, tehdy mladých, pro značnou část českých rusistických pracovišt'. Jaksi přirozeně přešla naše organizovaná setkání s profesorem Zahrádkou do neorganizovaných, z vykání jsme přešli na tykání (kterého jsem si vážil a vážím dodnes), $\mathrm{z}$ úcty $\mathrm{k}$ autoritě se stala úcta a ocenění staršího partnera, ve kterých ani pak z mé strany nešlo necítit notnou dávku respektu a uznání.

Dlouhá a zákeřná nemoc nakonec zvítězila. Namísto gratulace $\mathrm{k}$ devadesátinám píši nekrolog, snažím se být co nejméně osobní, ale nedaří se mi to. Uvědomuji si, že se cosi uzavřelo, že je něco definitivní, nezvratné a nevratné. 
Záslužná neúnavná práce profesora Miroslava Zahrádky zanechává trvalou a hodně hlubokou brázdu na poli české rusistiky, výsledky jeho práce stejně jako jeho památku nelze vymazat ani obejít.

fosef Dohnal

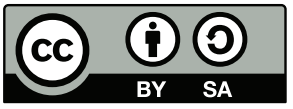

Toto dílo Ize užít v souladu s licenčními podmínkami Creative Commons BY-SA 4.0 International (<https:// creativecommons.org/licenses/by-sa/4.0/legalcode>). Uvedené se nevztahuje na díla či prvky (např. obrazovou či fotografickou dokumentaci), které jsou v díle užity na základě smluvní licence nebo výjimky či omezení príslušných práv. 